\title{
A ATUAÇÃO DA JUSTIÇA ELEITORAL E O CPC DE 2015: DECISÃO DE CASOS CONCRETOS, PRECEDENTES JUDICIAIS E PODER NORMATIVO
}

\author{
Aline Boschi Moreira ${ }^{1}$ \\ Pedro Henrique Reschke ${ }^{2}$
}

\section{RESUMO}

O trabalho aborda a atuação da Justiça Eleitoral e as implicações trazidas pela entrada em vigor do Código de Processo Civil de 2015. Como objetivo, analisa-se o sistema de precedentes judiciais na teoria do direito e no processo civil brasileiro a fim de, posteriormente, inseri-lo na práxis eleitoral. São aferidas, também, possíveis mudanças no comportamento da justiça especializada, em especial quanto ao poder normativo e à edição de enunciados de súmulas. Utilizam-se, no desenvolver do artigo, método dedutivo e procedimento de estudo de caso, sendo escolhida a Resolução TSE n. 23.376/2012 como objeto de pesquisa.

Palavras-Chave: Precedentes judiciais. CPC/15. Justiça Eleitoral. Poder Normativo.

\section{THE ROLE OF BRAZILIAN ELECTORAL JUSTICE AND THE NEW CIVIL PROCEDURE CODE: ADJUDICATION, PRECEDENT AND LAW-MAKING POWERS}

\begin{abstract}
The 2015 Brazilian Civil Procedure Code has brought about significant impact over the role of Brazilian Electoral Courts. This paper studies some of these changes, beginning by a study of judicial precedent, both in jurisprudence and in procedural law, while noting precedent's impact over the praxis of the Electoral Courts. Specific attention is devoted to whether this requires any specific changes in the behavior of said courts, specially regarding their lawmaking powers and the súmula. We used the deductive method and the case study procedure, by analyzing Resolution n. 23.376/2012, from the Tribunal Superior Eleitoral.
\end{abstract}

Keywords: Judicial Precedent. 2015 Brazilian Civil Procedure Code. Electoral Justice. Normative Power.

\footnotetext{
${ }^{1}$ Advogada. Mestra em Direito pela Universidade Federal de Santa Catarina - UFSC, Santa Catarina (Brasil).

E-mail: alineboschi@gmail.com

2 Advogado. Mestrando em Direito pela Universidade Federal de Santa Catarina - UFSC, Santa Catarina (Brasil). Especialista em Processo Civil pela Faculdade CESUSC.
} 


\section{INTRODUÇÃ̃O}

Muito se discute, na bibliografia científica brasileira, acerca da jurisprudência lotérica (CAMBI, 2001): trata-se de conjuntura de extrema insegurança jurídica trazida, dentre outros motivos, pela fragmentação das decisões. Nesse cenário de incerteza, uma das respostas oferecidas pelo legislador aposta na força obrigatória e vinculante dos provimentos judiciais como forma de efetivar o princípio da isonomia - não à toa que o Código de Processo Civil (CPC) de 2015 empresta gás renovado às súmulas e ao julgamento de causas repetitivas.

A par do quadro acima, o trabalho aborda as implicações trazidas pela entrada em vigor do CPC de 2015 na prática da Justiça Eleitoral. Ciente das competências específicas da justiça especializada (como seu poder normativo) e da aplicação subsidiária do codex na matéria, o ensaio investe nos novos papéis que se espera do órgão a partir da guinada metodológica proposta pela lei processual contemporânea.

A problemática busca esclarecer os limites da função regulamentar do Tribunal Superior Eleitoral (TSE), diferenciando hipóteses em que ela pode ser legitimamente exercida daquela em que é forçosa a emissão de enunciado sumular ou mesmo a permissividade da divergência, para que a discussão continue a amadurecer junto aos casos concretos.

Acerca dos objetivos e da divisão do trabalho, o primeiro tópico se ocupa em traçar noções introdutórias sobre o precedente judicial e seu contexto dentro do CPC de 2015. Pretende-se descrever o poder de criação judicial do direito pelo juiz e seu impacto vinculante em casos subsequentes, bem como as técnicas e as ferramentas inseridas pelo legislador para garantir a legitimidade na aplicação desse direito judiciário. Já a segunda seção retrata as novidades implementadas pelo Código de Processo Civil na Justiça Eleitoral, projetando possíveis mudanças de atuação do órgão, em especial quanto ao poder normativo e à edição de enunciados de súmulas.

Para tanto, utilizam-se, no desenvolver do artigo, método dedutivo e procedimento de estudo de caso, escolhendo-se a Resolução TSE n. 23.376/2012 como objeto de pesquisa pelas especificidades únicas ali observadas. 


\section{PRECEDENTES JUDICIAIS NA TEORIA DO DIREITO E NO PROCESSO CIVIL BRASILEIRO}

A primeira seção deste trabalho se ocupa em traçar noções introdutórias sobre o precedente judicial e seu contexto dentro do Código de Processo Civil (CPC) de 2015. Pretende-se descrever o poder de criação judicial do direito pelo juiz e seu impacto vinculante em casos subsequentes, bem como as técnicas e as ferramentas inseridas pelo legislador para garantir a legitimidade na aplicação desse direito judiciário.

\subsection{Criação judicial do direito}

Já não causa espanto aos juristas brasileiros a ideia de que o juiz cria direito. Não legisla da mesma forma que o Poder Legislativo, mas cria direito ao resolver casos concretos. Embora a comunidade científica pátria tenha só recentemente se debruçado sobre o fenômeno, a produção da norma jurídica individual e concreta pelo magistrado é parte integrante de qualquer teoria positivista moderna pelo menos desde Kelsen, que, em sua Teoria pura do direito, já sustentava oferecer a lei apenas uma moldura de sentido a ser posteriormente preenchida (2006, p. 390-391)

Todavia, é importante, de início, não confundir dois problemas que, apesar de semelhantes, são fundamentalmente distintos. Uma coisa é alegar que o magistrado cria direito no caso concreto; outra, bem diferente, é inferir que a atividade tem força vinculante sobre decisões futuras. Esta judge-made law com força obrigatória é rotineiramente apontada como característica do common law, dizendo-se, inclusive, não ter espaço em sistemas como o brasileiro, de civil law - nesse sentido Ferrajoli (2015, p. 140-143). Ainda que difícil traçar com rigor as origens históricas da bifurcação metodológica entre os dois sistemas, ela certamente se relaciona com os ideais de limitação do poder estatal proclamados pela Revolução Francesa: buscava-se minimizar a liberdade do juiz defendendo a subsunção

\footnotetext{
${ }^{3}$ Igual perspectiva segue a teoria do direito contemporânea, especialmente a anglo-saxônica, seja no exercício de poder discricionário, como em Hart (2012, p. 183-191), seja por meio da interpretação da integridade do fenômeno jurídico-político, a exemplo de Dworkin (1986, p. 228-232). Trata-se da faceta normativa da produção do direito de responsabilidade do Judiciário, exercida em complementação à faceta legislativa (GRAU, 2013 , p. 43-44).
} 
mecânica da lei produzida no parlamento (MARINONI, 2016, p. 43-48). Dessa forma, o Judiciário era visto como "poder neutro" e mera "boca que pronuncia as palavras da lei" (MONTESQUIEU, 1973, p. 78).

Aos poucos, realidade e doutrina vão de encontro à teoria iluminista. Atualmente, tende-se a admitir que o juiz produza direito, até porque o legislador não é onisciente e a lei não é unívoca, sendo ambos insuficientes para garantir que haja coerência e integridade no ordenamento jurídico. Assim, ao resolver um caso, os parâmetros traçados pelo texto legal são apenas o início da atividade jurisdicional, que deve somar as circunstâncias concretas e os princípios e regras constitucionais a fim de construir a resposta adequada ao problema - essa, agora, denominada norma jurídica (GRAU, 2013).

O processo acima descrito é preponderantemente argumentativo, de modo que é impossível falar em teoria do direito sem mencionar, ao mesmo tempo, teoria da argumentação (MACCORMICK, 2009, p. 299). E a legitimidade do decisum está estritamente vinculada à racionalidade argumentativa e às razões que o magistrado adota para julgar, sendo considerada democrática a decisão baseada num consenso construído discursivamente (HABERMAS, 1996, p. 170-173) - daí a importância do conceito de ratio decidendi para a adequada compreensão dos precedentes.

Aqui se encontra a justificativa mais elementar para o respeito aos precedentes judiciais identificada por Schauer, para quem o processo de decisão se compara à prática social de fazer promessas (2009, p. 179). Segundo o autor, dado que a fundamentação possui grau de universalidade maior que o veredito tomado, sempre que alguém expressa os motivos para adotar determinado ponto de vista, naturalmente, os demais participantes do processo de comunicação, cientes das razões escolhidas para resolver a lide, geram a expectativa de que tais argumentos sejam levados a casos análogos no futuro.

O exemplo de Schauer é singelo, mas elegante: se determinada pessoa carrega um guarda-chuva porque a previsão do tempo assinala a possibilidade de chover, há expectativa implícita de que o sujeito seguirá igual comportamento em todas as hipóteses futuras congêneres, mesmo que nada tenha sido dito expressamente (SCHAUER, 2009, p. 176). E se essa é uma das características de qualquer discurso, a responsabilidade dos tribunais é ainda maior, em virtude da garantia constitucional de tratamento igualitário dos jurisdicionados, o princípio da isonomia. É com base nisso que Mitidiero observa, na expectativa gerada pela 
motivação das decisões judiciais, separação inevitável entre o discurso da fundamentação e o do precedente (MITIDIERO, 2012).

Desse modo, é incorreta a ideia de que o juiz, no civil law, ao decidir, desobriga-se de olhar para as decisões que foram tomadas no passado. Se assim o fosse, a fragmentação da jurisprudência brasileira não geraria tanta insegurança e perplexidade, a ponto de recorrer ao Judiciário ser ato comparado a apostar na loteria (CAMBI, 2001). Apenas uma visão muito deturpada da independência judicial e do "princípio" do livre convencimento (STRECK, 2014, p. 74-85) poderia levar a crer que cada decisão é isolada de seu contexto social e histórico. O uso de decisões judiciais anteriores no processo de decisão judicial, percebe-se com facilidade, é um problema de teoria do direito, que afeta e deve ser compreendido por juristas do mundo todo, não apenas no common law (BUSTAMANTE, 2013).

Tendo em vista tais conclusões, o próximo tópico se dedica ao estudo das ferramentas inseridas pela Constituição, pela lei federal e pela prática judiciária brasileira para tentar reduzir a fragmentação mencionada.

\section{2 "Precedente à brasileira": teses vinculantes enunciadas pelo juiz precedente}

Não é inovador falar em precedentes judiciais no contexto do processo civil brasileiro. A preocupação em idealizar ferramentas que permitissem a adequada uniformização da jurisprudência se faz presente há muito tempo na lei. O artigo 853 do CPC de 1939, por exemplo, previa a divergência jurisprudencial como hipótese de cabimento de recurso de revista para os tribunais superiores. Na mesma linha, Barbosa Moreira, em seus comentários ao CPC de 1973, indicava o objetivo de "evitar, na medida do possível, que a sorte dos litigantes e afinal a própria unidade do sistema jurídico vigente [ficassem] na dependência exclusiva da distribuição do feito ou do recurso a este ou aquele órgão" (2008, p. $5)$.

Talvez um dos mais importantes e simbólicos instrumentos utilizados pelo direito pátrio seja a súmula de jurisprudência dominante. Arquitetada pelos ministros do Supremo Tribunal Federal (STF) em 1963, surge como forma de catalogar com facilidade os principais entendimentos da corte, mas seus enunciados, estruturados como verbetes gerais e abstratos, não demoram a ter, eles próprios, força vinculante (ZANETI JR., 2014, p. 191-192). Tal 
anotação histórica dá o tom de todas as reformas subsequentes: as alterações legislativas não tardam a dotar com natureza obrigatória as decisões dos tribunais de segunda instância.

Nessa seara, torna-se habitual, para os juristas brasileiros, esperar que a corte julgadora do caso precedente enuncie, ela própria, a tese jurídica que resulta do acórdão. Não menos incomum, e incidindo no erro metodológico aqui criticado, é o emprego mecânico da tese jurídica aos casos futuros, como se ela fosse mero resultado de processo interpretativo. O precedente, que deveria ser visto como ponto de partida para a interpretação e a criação do direito em casos ulteriores - e a metáfora da novela em cadeia de Dworkin (1986, p. 282) é explicação adequada do fenômeno - acaba se transformando num elemento de fechamento, de teses jurídicas que resolvem problemas antes que eles surjam. Rossi chama esse fenômeno de "precedente à brasileira" (2015). Outra parte da doutrina enxerga o processo de "objetivação" do processo civil brasileiro como uma tendência benéfica (WOLKART, 2013).

$\mathrm{O}$ fato é que a crescente inquietude com a fragmentação da jurisprudência faz com que se aposte cada vez mais nesse tipo de força obrigatória. Exemplo de relevo foi a inserção do instituto da súmula vinculante e da repercussão geral como requisito de admissibilidade do recurso extraordinário, incluídas por meio da Emenda Constitucional n. 45, de 2004. Reconhecendo o papel do STF como intérprete último da Constituição, o constituinte derivado concebeu mecanismos para a criação de teses jurídicas vinculantes, cuja base ideológica das reformas, indicada pela doutrina, é o quase incontroverso diagnóstico da necessidade de aproximação com o common law e o stare decisis (CÔRTES, 2008).

O CPC de 2015, embora cercado de normas programáticas e principiológicas que visam a mitigar o efeito negativo da vinculação a teses criadas em abstrato (análise feita a seguir), define diversos provimentos que funcionam justamente por meio desse mecanismo. $\mathrm{O}$ artigo 927, a respeito, elenca uma lista deles (regulados em detalhe em outros pontos do código), emprestando renovada força à súmula dos tribunais superiores bem como ao sistema de julgamento de causas repetitivas (artigo 9284):

\footnotetext{
${ }^{4} \mathrm{O}$ sistema de julgamento de causas repetitivas, segundo o artigo 928, é composto pelos recursos especial e extraordinário repetitivos e pelo incidente de resolução de demandas repetitivas. Todos funcionam de forma parecida, uma vez que, a partir de causas que envolvam matérias de direito semelhantes, questões jurídicas análogas são extraídas e julgadas em abstrato. Desse modo, fixa-se tese jurídica a todas as situações préexistentes e com força de precedente vinculante para demandas futuras. Existe, contudo, grande dissociação entre a tese jurídica, definida em abstrato, e os fatos do caso concreto, porquanto o CPC prevê expressamente que a definição daquela deve ocorrer em separado do julgamento deste (vejam-se os artigos 980, parágrafo único, e $\left.1.037, \S 7^{\circ}\right)$.
} 
Art. 927. Os juízes e os tribunais observarão:

I - as decisões do Supremo Tribunal Federal em controle concentrado de constitucionalidade;

II - os enunciados de súmula vinculante;

III - os acórdãos em incidente de assunção de competência ou de resolução de demandas repetitivas e em julgamento de recursos extraordinário e especial repetitivos;

IV - os enunciados das súmulas do Supremo Tribunal Federal em matéria constitucional e do Superior Tribunal de Justiça em matéria infraconstitucional;

$\mathrm{V}$ - a orientação do plenário ou do órgão especial aos quais estiverem vinculados.

Conquanto seja o principal mecanismo de vinculação, o artigo 927 não deve ser interpretado isoladamente, sob pena de se atenuar a necessidade argumentativa das decisões. Felizmente, não passaram despercebidos os possíveis resultados deletérios que adviriam de modelo processual brasileiro baseado apenas em teses abstratas mecanicamente utilizadas. Tendo em consideração tais preocupações, foram inseridas ferramentas que almejam a aplicação escorreita desse poder judicial de criação do direito através de teses vinculantes tanto no momento de redação, quanto no seu emprego futuro.

Leitura sistêmica do Código transparece que o legislador buscou não apenas criar provimentos vinculantes isolados, mas efetivo sistema de precedentes. Forte sinalização se encontra no artigo 926: "Os tribunais devem uniformizar sua jurisprudência e mantê-la estável, íntegra e coerente". A generalidade do dispositivo, unida aos conceitos de estabilidade, integridade e coerência, sugere que se está diante da tentativa de releitura da prática forense.

Some-se, também, o extenso dever de fundamentação posto pelo artigo $489, \S 1^{\circ}$, especialmente nos seus incisos V e VI, os quais barram a subsunção cartesiana das teses em abstrato e permitem seu uso somente com menção aos casos concretos que lhes deram origem. Em relação às súmulas, ainda, o CPC obriga os tribunais a fixarem-nas em atenção "às circunstâncias fáticas dos precedentes que motivaram sua criação” (artigo 926, § 2º, grifo nosso), até porque, como fontes de pesquisa e indexadoras de jurisprudência que são, devem apontar para a ratio decidendi dos precedentes que a geraram (ABBOUD; LUNELLI; SCHMITZ, 2014, pp. 666-667).

Tudo isso aponta a investida de fomentar, por meio do CPC, cultura argumentativa, sem a qual o efeito vinculante do precedente, das súmulas e das teses jurídicas pode ser visto como "um pretexto para a mera produção de normas discricionárias pelos tribunais" 
(BUSTAMANTE, 2015, p. 296). O grande desafio é conceitual: diferentemente do rol do artigo 927, que institui consequência direta e objetiva para o descumprimento da tese jurídica (a cassação da decisão), as normas principiológicas não trazem qualquer força coativa sobre os agentes públicos que com elas lidam. Passa unicamente a depender, logo, de aspectos sociológicos e culturais dos juristas (SCHAUER, 2009, p. 77-82).

Quer dizer, a mudança não será conquistada só pela nova lei, é preciso que ela própria seja lida a partir das considerações aqui expostas. Do contrário, o sistema de precedentes idealizado pelo CPC padecerá dos mesmos defeitos do instituto dos assentos do direito lusitano. Os assentos, muito semelhantes à súmula vinculante, foram declarados inconstitucionais pelo Supremo Tribunal de Justiça Português, que acatou as críticas feitas por Castanheira Neves. Para o autor, a importância de buscar a unidade do direito, embora faceta indispensável da função das cortes superiores, "não traduz uma teleologia contrária à da justa ou materialmente adequada decisão concreta dos casos jurídicos” (2014, p. 687).

A título de conclusão parcial, o tópico demonstra a conjuntura delicada que se desenha hoje perante o profissional do direito brasileiro. A linha entre a solução do problema da fragmentação das decisões e a excessiva padronização da prestação jurisdicional é tênue. As súmulas e teses jurídicas em abstrato não expressam a resposta ideal ao problema da jurisprudência lotérica, para relembrar Cambi (2001), mas são o caminho traçado pelo ordenamento positivo pátrio - e é dever de ofício de todos os juristas o conhecimento dos problemas desse método, bem como o uso das ferramentas para solucioná-los.

\section{AS IMPLICAÇÕES DO NOVO CPC NA JUSTIÇA ELEITORAL}

Que o CPC de 2015 é utilizado subsidiariamente no processo eleitoral é de obviedade pueril, decorrência do funcionamento do sistema jurídico pátrio e expressamente previsto no artigo 15 ("Na ausência de normas que regulem processos eleitorais, trabalhistas ou administrativos, as disposições deste Código lhes serão aplicadas supletiva e subsidiariamente"). Disso sucede que, ante a falta de arranjo especifico sobre o precedente na seara especializada, as disposições acima também se desdobram no direito eleitoral.

Faz-se necessária, porém, uma ressalva acerca da amplitude de tal influência. A dimensão do poder criativo da Justiça Eleitoral é muito superior à da justiça comum, pois, além de todos os instrumentos descritos, existe, ainda, a possibilidade de se emitirem atos 
regulamentares infra legem. Como se vê, o risco de discricionariedade e de violação aos limites desse poder (que, repita-se, deve ser legitimado pela fundamentação e vinculado à solução de casos concretos) é ainda maior.

Por isso, os próximos subitens se ocupam da função normativa do Tribunal Superior Eleitoral (TSE), diferenciando hipóteses em que ela pode ser legitimamente exercida daquela em que é forçosa a emissão de enunciado sumular - ou mesmo a permissividade da divergência, para que a discussão continue a amadurecer junto aos casos concretos.

\subsection{Justiça Eleitoral e a expedição de atos normativos ${ }^{5}$}

A Justiça Eleitoral, prevista desde 1932, é órgão sui generis, cuja organização dificilmente se observa nos ordenamentos dos demais países ${ }^{6}$. A ela incumbe, dentre outras atribuições que não interessam ao presente tópico ${ }^{7}$, o exercício da jurisdição e o poder normativo. Ao passo que a competência para conhecer e julgar as causas propostas funciona da forma discutida no capítulo antecedente, aborda-se, agora, a segunda função, matéria que gera debates acalorados na doutrina brasileira - em parte esquecidos pela prática cotidiana dos tribunais.

Aqui empregado como sinônimo de atividade regulamentar ${ }^{8}$, o poder normativo é uma das principais distinções da justiça especializada frente aos demais órgãos do Poder Judiciário (GOMES, 2016), sendo concebido pelo legislador no Código Eleitoral (Lei n. 4.737/1965), na Lei das Eleições (Lei n. 9.504/1997) e na Lei Orgânica dos Partidos Políticos (Lei n. 9.096/1995).

Os debates quanto à sua legitimidade se fundam justamente na ausência de previsão constitucional e na necessidade de lei complementar para dispor sobre a competência dos

\footnotetext{
${ }^{5} \mathrm{O}$ subitem é desenvolvido com base em tópico da dissertação de mestrado de um dos coautores, com as devidas adaptações para o artigo científico.

${ }^{6}$ A título de exemplo, a Federal Election Commission (FEC) é agência reguladora independente, não compondo os quadros da justiça estadunidense. Da mesma forma, a Elections Canada é agência apartidária responsável por conduzir as eleições federais no Canadá.

${ }^{7}$ Como o poder consultivo e a função administrativa, a qual engloba o alistamento e a transferência eleitorais, a organização dos pleitos, o registro de partidos políticos, a diplomação dos eleitos e, para Nobre Junior (2001), o controle da propaganda eleitoral e partidária (poder de polícia).

${ }^{8}$ Embora se reconheça a divergência trazida por DiPietro (2007), para quem o poder normativo é gênero do qual se extraem: 1) a expedição de atos derivados (poder regulamentar propriamente dito) e 2) a promulgação de atos normativos originários que inovam no ordenamento jurídico.
} 
tribunais, dos juízes e das juntas eleitorais (artigo 121 da CRFB/1998). Dessa forma, parte da literatura sustenta ser inconstitucional a atribuição conferida, dado que não reiterada pelo constituinte nem prevista em lei qualificada - nesse sentido, a tese de Salgado (2010). Por outro lado, admissível recepcionar a Lei n. 4.737/1965 como se norma complementar fosse, inclusive porque, na década de 60 do século passado, segundo esclarece Barros (2007), inexistia essa espécie normativa. Assim, e também por analogia ao tratamento concedido ao Código Tributário Nacional, defensável confiar ao Código Eleitoral status de lei complementar, reconhecendo-se a legalidade das competências ali descritas.

O questionamento se volta, logo, no que consiste tal previsão, sendo que, para melhor entendimento, necessário colacionar os artigos que a acolhem, mesmo aqueles posteriores à Carta de 1988, até porque há pouca diferença na escrita:

\section{Lei n. 4.737/1995}

Art. $1^{\circ}$ Parágrafo Único. O Tribunal Superior Eleitoral expedirá as instruções para sua fiel execução.

Art. 23 - Compete, ainda, privativamente, ao Tribunal Superior, [...]

IX - expedir as instruções que julgar convenientes à execução deste Código;

Lei n. 9.504/1997

Art. 105. Até o dia 5 de março do ano da eleição, o Tribunal Superior Eleitoral, atendendo ao caráter regulamentar e sem restringir direitos ou estabelecer sanções distintas das previstas nesta Lei, poderá expedir todas as instruções necessárias para sua fiel execução, ouvidos, previamente, em audiência pública, os delegados ou representantes dos partidos políticos. [...]

$\S 3^{\circ}$ Serão aplicáveis ao pleito eleitoral imediatamente seguinte apenas as resoluções publicadas até a data referida no caput.

Lei n. 9.096/1995

Art. 61. O Tribunal Superior Eleitoral expedirá instruções para a fiel execução desta Lei.

Antes de analisá-los, importante esclarecer que a seara administrativista - por todos vejam-se Carvalho Filho (2012) e Meirelles (2002) - distingue o que se compreende por instruções, regulamentos e resoluções. Dizem os estudiosos que as primeiras são atos expedidos para organizar as atividades e os órgãos internos da Administração Pública; os segundos - de competência exclusiva do chefe do Executivo - almejam a fiel execução de lei; e as últimas procuram disciplinar matéria específica por quem não exerce a função de governo.

Cotejando a divisão acima com o Código Eleitoral, a Lei das Eleições e a Lei Orgânica dos Partidos Políticos, observa-se que o Congresso Nacional não procedeu com o devido rigor técnico, uma vez que utiliza o termo "instrução" para o ato de "executar a lei", 
sendo que a Justiça Eleitoral não integra o Poder Executivo. Ora, melhor seria adotar um dos seguintes textos: compete ao Tribunal Superior Eleitoral a) expedir resoluções para a fiel execução de lei; ou b) expedir instruções para organizar a atividade administrativa interna.

Devido à miscelânea linguística, a literatura brasileira chega a diversas conclusões. Uma delas, capitaneada por Salgado (2010), alega que o poder normativo da Justiça Eleitoral está adstrito a elaborar regimentos no intuito de coordenar a sua prática interna corporis. Posicionamento outro ignora o termo "instrução" e sustenta a possibilidade de a justiça especializada expedir resoluções para operacionalizar as leis eleitorais. A práxis do Tribunal Superior Eleitoral vai ao encontro desta vertente, denominando os atos normativos de resoluções e, na maioria das vezes (com significativas exceções), buscando instrumentalizar o ordenamento jurídico.

A atuação, contudo, não se reveste de poderes absolutos, estando limitada, em especial, pela legalidade (artigo 5 ${ }^{\circ}$, inciso II, da CRFB/1988). É falar, portanto, na vedação de “expedir regulamento, instrução, resolução, portaria [...] para coatar a liberdade dos administrados, se em lei já existir delineada a contenção ou imposição que o ato administrativo venha a minudenciar" (MELLO, 2013, p. 106). Destarte, recepciona-se a prevalência da lei sobre os regulamentos, proibindo-se - com exceção ao controverso artigo 84, inciso VI, alínea a, da CRFB/1988, que não faz parte do presente exame - atos normativos secundários que inovem, modifiquem, suspendam ou revoguem lei ou documentos a ela equiparados (ATALIBA, 2007; CANOTILHO, 1993; MENDES; COELHO; BRANCO, 2008).

Inclusive, não é demais lembrar que, em matéria eleitoral, é vedada a edição de medida provisória e de lei delegada (artigo 62, $\S 1^{\circ}$, inciso I, alínea a, e artigo $68, \S 1^{\circ}$, inciso II, ambos da CRFB/1988), não sendo a resolução, logo, instrumento capaz de afastar a atuação do parlamento.

Dito isso, o ponto incisivo da pesquisa se volta à escolha de como a Justiça Eleitoral deve atuar no processo eletivo: seja por meio da edição de súmulas, seja por resoluções ou, ainda, decidindo o caso concreto e confiando na força vinculante do precedente. Para tanto, busca-se formular possível resposta valendo-se do método de estudo de casos, em que se escolhe a Resolução n. 23.376/2012 como objeto de análise, por tratar-se de situação em que, na percepção dos autores, o TSE agiu de maneira indevida. 


\subsection{Formas de atuação da Justiça Eleitoral: um estudo de caso}

A Resolução TSE n. 23.376/2012 - aprovada em março de 2012 por maioria de quatro votos a três ${ }^{9}$ - dispôs acerca da arrecadação e dos gastos de recursos por partidos políticos, candidatos e comitês financeiros (atualmente extintos pela Lei n. 13.165/2015) e, ainda, sobre a prestação de contas nas eleições municipais daquele período. Sua versão original, posteriormente modificada em juízo de retratação ${ }^{10}$, determinava que "a decisão que desaprovar as contas de candidato implicará o impedimento de obter a certidão de quitação eleitoral" ( $\$ 2^{\circ}$ do artigo 52, grifo nosso).

Muito brevemente, sabe-se que a prestação de contas eleitorais é procedimento indispensável que garante a accountability de tudo que foi obtido e desembolsado pelos candidatos e partidos políticos em período de campanha. Velando a Justiça Eleitoral pela regularidade financeira no processo eletivo, facultam-lhe as seguintes decisões: pela aprovação da contabilidade, quando regulares; pela aprovação com ressalvas, se verificadas falhas que não a comprometam; pela desaprovação; e pela não prestação (artigo 30 e incisos da Lei n. 9.504/1997).

Até as eleições de 2008, não era incomum que os competidores vencidos deixassem de entregar o relatório contábil ao juiz competente (ou seja: tinham sentença declarando não terem sido prestadas as contas) sem que isso acarretasse consequências jurídicas - os vencedores, a seu tempo, eram obrigados a encaminhá-lo para a diplomação (artigo $29, \S 2^{\circ}$, da Lei n. 9.504/1997). A impunidade cessou, em parte, ao se incluir o $§ 7^{\circ}$ ao artigo 11 da Lei das Eleições em 2009:

$\S 7^{\circ}$ A certidão de quitação eleitoral abrangerá exclusivamente a plenitude do gozo dos direitos políticos, o regular exercício do voto, o atendimento a convocações da Justiça Eleitoral para auxiliar os trabalhos relativos ao pleito, a inexistência de multas aplicadas, em caráter definitivo, pela Justiça Eleitoral e não remitidas, e a apresentação de contas de campanha eleitoral. (Incluído pela Lei n. 12.034, de 2009)

\footnotetext{
${ }^{9}$ Vencidos os ministros Arnaldo Versiani, Gilson Dipp e Marcelo Ribeiro.

${ }^{10}$ Devido à mudança na composição do Tribunal Superior Eleitoral, sagraram-se vencedores os ministros Arnaldo Versiani, Gilson Dipp, Dias Toffoli e Henrique Neves.
} 
Um primeiro olhar sugere que, enfim, o ardil daqueles que se furtavam de agir com transparência havia sido evitado: a falta de apresentação de contas de campanha passa a ser sancionada com a ausência de quitação eleitoral e, logo, o sujeito carece de condição de elegibilidade para concorrer futuramente. A conclusão é feita a partir do seguinte raciocínio: se o registro de candidatura deve ser instruído com a certidão de quitação eleitoral ${ }^{11}$ e esta abarca a entrega da prestação de contas, quem está em mora com a justiça não pode ser candidato.

Após a minirreforma, nas eleições gerais de 2010, e já antecipando brecha legal, muitos concorrentes passaram a apresentar relatórios arguindo a inexistência de arrecadação e de gastos eleitorais, hipótese que, como visto, embora não acarretasse o decisum pela "não apresentação", ocasionava, via de regra, a "desaprovação" das contas. Tal prática generalizouse, com diversos concorrentes anexando declarações de não movimentação financeira no período de escrutínio. Com isso, evitava-se tanto a ausência de condição de elegibilidade, quanto a necessidade de transparecer as doações e as despesas efetuadas.

Tendo conhecimento do ocorrido, decidiu o Tribunal Superior Eleitoral, para o pleito de 2012, inserir item específico na Resolução n. 23.376, dispondo que não apenas a falha na apresentação de contas gerava a negativa de quitação eleitoral, mas também a sua desaprovação (artigo 52, § $2^{\circ}$ ).

Apesar de posteriormente revogado em juízo de retratação, interessa ao presente exame averiguar se a justiça especializada procedeu com a devida técnica processual ao introduzir o dispositivo ou se há outras ferramentas mais adequadas para a solução do caso. Nota-se, ademais, que não se está adentrando em juízo de valor se correto ou errado o conteúdo da posição dos ministros, uma vez que se aventa tão-só o aspecto formal do ato ${ }^{12}$.

De modo antecipado, o trabalho sustenta as seguintes premissas: 1) que o uso do poder normativo não foi adequado na hipótese em tela; e 2) que a edição de enunciado de súmula ou a decisão de casos concretos seriam atividades mais acertadas.

${ }^{11}$ Lei n. 9.504/1997, Artigo 11, § $1^{\circ} \mathrm{O}$ pedido de registro deve ser instruído com os seguintes documentos: VI - certidão de quitação eleitoral [...].

${ }^{12}$ Para ler a respeito do aspecto material do ato normativo: Barros (2012), Cruz (2012), Silva (2012) e o TCC de um dos coautores. 
A proposição inicial tem por fundamento o fato de que, a priori, o artigo legal não visava a operacionalizar a lei, mas interpretava o alcance do termo "contas não apresentadas", que, para os ministros, haveria de incluir aquelas prestações entregues (e, consequentemente, prestadas) sem qualquer movimentação financeira (julgadas desaprovadas). Numa visão administrativista, poder-se-ia dizer que o ato era dirigido aos funcionários da Justiça Eleitoral, alertando-os para não emitirem documento de quitação se apurada a carência de accountability.

Ocorre que a redação tinha destinatário certo, era encaminhada aos candidatos, aos partidos políticos e, à época, aos comitês financeiros, obrigando-os a prestarem contas de forma efetiva, sob pena de nova consequência jurídica (a falta de quitação eleitoral). Fala-se nova porque sempre existiram penalidades pela desaprovação de contas, a exemplo das sanções do artigo 30-A da Lei n. 9.504/1997 e da ação de investigação judicial eleitoral (artigo 22 da Lei Complementar n. 64/1990).

Outro ponto relevante para a premissa reside na modulação dos efeitos do dispositivo, ou seja, se ele valeria para as eleições passadas ou somente dali para frente, pendência jurídica sem maioria formada. A simples discussão acerca da (ir)retroatividade normativa aventa que a matéria é mais profunda que a de executar as regras eleitorais. A opção entre seguir a Lei da Ficha Limpa ou não penalizar aqueles com sentença desfavorável nos pleitos anteriores ${ }^{13}$ demonstra que o $\S 2^{\circ}$ do artigo 52 da Resolução n. 23.376/2012 trazia mais dúvidas do que esclarecimentos.

De se questionar, até mesmo, se recomendada a edição de enunciado de súmula no presente caso, porquanto o Tribunal Superior Eleitoral mudou de posicionamento diversas vezes em menos de quatro anos ${ }^{14}$ - e a súmula, como dito, é instrumento que deve refletir a jurisprudência dominante, da qual é mera indexadora. Numa primeira interpretação, por maioria mínima, entenderam os ministros que a quitação eleitoral deveria abranger a aprovação das contas. Em seguida, novamente por 4x3, após a minirreforma de 2009, o quadro predominante foi o de se obter a certidão apenas com a entrega da contabilidade.

\footnotetext{
${ }^{13}$ Nas sessões administrativas, a Ministra Nancy Andrghi, relatora do voto vencedor, afirmou que havia mais de vinte mil cidadãos com contas desaprovadas que podiam retirar a certidão de quitação eleitoral antes da Resolução n. 23.376/2012, mas que poderiam ser obstados com a publicação do ato normativo.

${ }^{14}$ Em parte, a fragmentação da jurisprudência ocorre pela própria composição da justiça especializada, que não se dá por membros de carreira, mas por mandato, ocasionando grande rotatividade entre os juízes.
} 
Enfim, fixa-se a redação do $\S 2^{\circ}$ no julgamento do Processo Administrativo n. 594-59, com retorno à decisão inicial, mas cujo parágrafo é revogado em juízo de retratação.

Com base nesses apontamentos, conclui-se que a hipótese em apreço merecia maior amadurecimento argumentativo e pacificação jurisprudencial no intuito de resguardar a isonomia e a segurança jurídica no processo eletivo. Dessa forma, não se concorda com a solução proferida pelo TSE de inserir o entendimento jurídico em ato normativo infra legem, tampouco se compreende que o estado da arte indicaria a formulação de enunciado de súmula. Isso posto, o recurso adequado, conforme a exposição até agora delineada, sugere que a celeuma seja resolvida mediante a decisão de casos concretos, até que o tempo e o costume esbocem posição mais robusta, estável e vinculante.

\section{CONCLUSÃO}

O artigo trata da influência do Código de Processo Civil de 2015 na atuação da Justiça Eleitoral, numa perspectiva que, embora preponderantemente descritiva, tem como objetivo desenvolver estudo crítico e prático.

A exposição inicia pelo valor das decisões no processo judicial a partir da teoria do direito, para, em seguida, analisar a incorporação de seus fundamentos pela lei processual brasileira. Na técnica descrita pelo legislador pátrio, o ato de interpretar o precedente para dele se extrair a razão de decidir não é atividade do juiz subsequente, mas daquele que julga o caso paradigma - espera-se que de cada precedente seja retirada regra geral e abstrata, desvinculada dos fatos da vida.

Disso surge a necessidade de mecanismos que garantam a legitimidade de tais regras, a fim de que a criação judicial do direito não ultrapasse os limites fáticos de cada demanda. Caminham nesse sentido os dispositivos como o dever de fundamentação (artigo 489, $\S 1^{\circ}$, especialmente os incisos V e VI), a obrigação de que o enunciado de súmula seja redigido em atenção às circunstâncias fáticas dos casos (artigo 926, § $2^{\circ}$ ) e a imposição generalizada de estabilidade, coerência e integridade da jurisprudência (artigo 926, caput). Todos apontam a necessidade de se implantar cultura argumentativa do precedente judicial, muito além de mero rol de provimentos vinculantes. 
Não é demais lembrar que, na ausência de normas que regulem os processos eleitorais, as disposições do CPC de 2015 são de aplicação supletiva e subsidiária. Decorre, portanto, que o sistema acima pode ser incorporado à justiça especializada como forma de repensar a atuação do Judiciário e a sua interferência nos escrutínios. Para tanto, necessário debater não apenas a atividade jurisdicional do órgão (que se vale dos contributos do novo Código), como também o seu controverso poder normativo. Embora alguns autores sustentem a inconstitucionalidade desta competência, a prática cotidiana passa ao largo das discussões: com frequência, são expedidas resoluções no intuito de, na maioria das vezes, operacionalizar o ordenamento legislativo.

Logo, o ponto incisivo da pesquisa se volta à escolha de como o Tribunal Superior Eleitoral deve atuar no processo eletivo. Tem-se, segundo o estudo da Resolução TSE n. 23.376/2012, que o seu papel deve ser conjugado às regras sobre o emprego do precedente previstas no CPC de 2015. Nas hipóteses em que houver controvérsia, deve a atuação da Justiça Eleitoral privilegiar a resolução de casos concretos e, quando efetivamente fixada jurisprudência dominante, a redação de enunciado sumular. A seu tempo, a competência de emitir atos normativos fica relegada, quando admitida, a executar a lei.

A questão é, acima de tudo, de controle. Afora os poderes regulamentares, a justiça especializada está sujeita aos mesmos critérios e limites que os demais órgãos do Judiciário. Cada atividade em seu lugar: a resolução normativa não pode servir para solucionar controvérsias, nem para interpretar assuntos legais polêmicos; a súmula deve refletir a jurisprudência dominante, não ser utilizada como forma de pacificá-la; e, onde possível, o sistema de precedentes deve girar em torno da vinculação da ratio decidendi extraída das decisões obtidas a partir dos casos concretos. 


\section{REFERÊNCIAS}

ABBOUD, Georges; LUNELLI, Guilherme; SCHMITZ, Leonard Ziesemer. Como trabalhar e como não trabalhar - com súmulas no Brasil: um acerto de paradigmas. In: MENDES, Aluisio Gonçalves de Castro; MARINONI, Luiz Guilherme, ARRUDA ALVIM WAMBIER, Teresa (orgs.). Direito jurisprudencial II. São Paulo: Revista dos Tribunais, 2014. vol. 2, p. 645-688.

ATALIBA, Geraldo. República e Constituição. São Paulo: Malheiros, 2007.

BARBOSA MOREIRA, José Carlos. Comentário ao Código de Processo Civil - arts. 476 a 565. 14. ed. Rio de Janeiro: Forense, 2008. vol. 5.

BARROS, Edilson Santos. A lei complementar e o seu processo de elaboração na Câmara dos Deputados. 2007. 63 f. Monografia (Especialização em Processo Legislativo) - Câmara dos Deputados, Brasília, 2007. Disponível em: <http://www2.camara.leg.br/>. Acesso em: 15 dez. 2016.

BARROS, Francisco Dirceu. O TSE acertou, mas não isentou os “contas sujas". Jus Navigandi, Teresina, ano 17, n. 3291, 5 jul. 2012 . Disponível em: < http://www.gnmp.com.br/publicacao/122/o-tse-acertou-mas-nao-isentou-os-contas-sujas>. Acesso em: 8 set. 2016.

BRASIL. Constituição (1988). Vade mecum. 21. ed. São Paulo: Saraiva, 2016.

Decreto-Lei n. 1.608, de 18 de setembro de 1939. Disponível em: <http://www.planalto.gov.br/ccivil_03/decreto-lei/1937-1946/Del1608.htm>. Acesso em 8 set. 2016.

Saraiva, 2016.

Lei Federal n. 4.737, de 15 de julho de 1965. Vade mecum. 21. ed. São Paulo:

. Lei Federal n. 9.096, de 19 de setembro de 1995. Vade mecum. 21. ed. São Paulo: Saraiva, 2016.

Lei Federal n. 9.504, de 30 de setembro de 1997. Vade mecum. 21. ed. São Paulo: Saraiva, 2016.

. Lei Federal n. 13.105, de 16 de março de 2015. Vade mecum. 21. ed. São Paulo: Saraiva, 2016.

Tribunal Superior Eleitoral. Processo Administrativo n. 594-59. Relatora

Designada: Ministro Enrique Ricardo Lewandowiski. Publicação: Diário da Justiça Eletrônico de 23 de setembro de 2010, Página 21. Brasília, Distrito Federal, 03 de agosto de 2010. 
Tribunal Superior Eleitoral. Resolução n. 22.376/2012. Relator: Ministro Arnaldo Versiani Leite Soares. Publicação: Diário da Justiça Eletrônico, Tomo 43, Disponibilizado 05 de março de 2012, p. 45-61, Republicado: Diário da Justiça Eletrônico, Tomo 143, Disponibilizado 27 de julho de 2012, p. 3-14. Brasília, Distrito Federal, $1^{\circ}$ de março de 2012. Disponível em: <http://www.tre-sc.jus.br/site/legislacao/resolucoes/tse/2012/res-tse-n233762012/index.html >. Acesso em: 01 ago. 2016.

BUSTAMANTE, Thomas da Rosa de. A dificuldade de se criar uma teoria argumentativa do precedente judicial e o desafio do Novo CPC. In: DIDIER JR., Fredie, et. al. Precedentes. Salvador: JusPodivm, 2015 (Coleção Grandes Temas do Novo CPC, v. 3).

Teoria do precedente judicial: a justificação e a aplicação de regras jurisprudenciais. São Paulo: Noeses, 2012.

CAMBI, Eduardo. Jurisprudência lotérica. Revista dos Tribunais, v. 90, n. 786, abr. 2001. p. 108-128.

CANOTILHO, José Joaquim Gomes. Direito Constitucional. 6. ed. Coimbra: Livraria Almedina, 1993.

CARVAlHO FILHO; José dos Santos. Manual de Direito Administrativo: até a Lei n. 12.587/2012. 25. ed. São Paulo: Atlas, 2012.

CASTANHEIRA NEVES, António. O instituto dos "assentos" e a função jurídica dos supremos tribunais. Coimbra (Portugal): Coimbra Editora, 2014.

CÔRTES, Osmar Mendes Paixão. Súmula vinculante e segurança jurídica. São Paulo: Revista dos Tribunais, 2008.

CRUZ, Danilo N. Reprovação de contas de campanha não impede a candidatura. 2012. Disponível em: <http://piauijuridico.blogspot.com.br/2012/07/ate-o-momento-esta-foidecisao-judicial.html>. Acesso em: 03 ago. 2016.

DIPIETRO, Maria Sylvia Zanella. Direito Administrativo. 20. ed. São Paulo: Atlas, 2007.

DWORKIN, Ronald. Law's empire. Oregon (Estados Unidos da América): Hart Publishing, 1986.

FERRAJOLI, Luigi. A democracia através dos direitos. São Paulo: Revista dos Tribunais, 2015.

GOMES, José Jairo. Direito Eeitoral. 12. ed. Belo Horizonte: Del Rey, 2016.

GRAU, Eros. Por que tenho medo dos juízes. 6. ed. São Paulo: Malheiros, 2013.

HABERMAS, Jürgen. Between facts and norms. Massachusetts (Estados Unidos da América): MIT Press, 1996. 
HART, Herbert Lionel Adolphus. O conceito de direito. São Paulo: Martins Fontes, 2012.

KELSEN, Hans. Teoria pura do direito. 7. ed. São Paulo: Martins Fontes, 2006.

MACCORMICK, Neil. Argumentação jurídica e teoria do direito. 2. ed. São Paulo: Martins Fontes, 2009.

MARINONI, Luiz Guiherme. Precedentes obrigatórios. 4. ed. São Paulo: Revista dos Tribunais, 2016.

MEIRELLES, Hely Lopes. Direito Administrativo brasileiro. 27. Ed. São Paulo: Malheiros, 2002.

MELLO, Celso Antônio Bandeira de. Curso de Direito Administrativo. 30 ed. São Paulo: Malheiros, 2013.

MENDES, Gilmar Ferreira; COELHO, Inocêncio Mártires; BRANCO, Paulo Gustavo Gonet. Curso de Direito Constitucional. 3 ed. Saraiva: São Paulo, 2008.

MITIDIERO, Daniel. Fundamentação e precedente - dois discursos a partir da decisão judicial. Revista de processo, São Paulo, v. 206, abr. 2012. p. 61-78.

MONTESQUIEU, Charles de Secondat. Do espírito das leis. São Paulo: Abril Cultural, 1973.

NOBRE JUNIOR, Edilson Pereira. Justiça Eleitoral: organização e competência. Revista Paraná Eleitoral, Curitiba, n. 40, 2001.

ROSSI, Júlio Cesar. Precedente à brasileira: a jurisprudência vinculante no $\mathrm{CPC}$ e no novo CPC. São Paulo: Atlas, 2015.

SALGADO, Eneida Desiree. Princípios constitucionais eleitorais. Belo Horizonte: Fórum, 2010.

SCHAUER, Frederick. The force of law. Massachusetts (Estados Unidos da América): Harvard University Press, 2015.

Thinking like a lawyer: a new introduction to legal reasoning. Massachusetts (Estados Unidos da América): Cambridge University Press, 2009

SILVA, Felipe Scabello. Por que a Resolução 23.376 do TSE não impede que os candidatos com contas de campanha desaprovadas em 2010 sejam candidatos em 2012? Jus Navigandi, Teresina, ano 17, n. 3219, 24 abr. 2012 . Disponível em: < http://www.egov.ufsc.br/portal/conteudo/por-que-resolu\%C3\%A7\%C3\%A3o-23376-do-tse- 
n\%C3\%A3o-impede-que-os-candidatos-com-contas-de-campanha-desaprov>. Acesso em: 8 set. 2016.

STRECK, Lenio. Hermenêutica jurídica e(m) crise. Porto Alegre: Livraria do Advogado, 2014.

WOLKART, Erik Navarro. Precedente judicial no processo civil brasileiro: mecanismos de objetivação do processo. Salvador: JusPodivm, 2013.

ZANETI JR., Hermes. O valor vinculante dos precededentes. Salvador: JusPodivm, 2014. 